\section{Gaudí y Jujol en Mallorca: vaya par}

Xumeu Mestre Arquitecto, Escola Tècnica Superior d'Arquitectura de Barcelona Elías Torres Arquitecto, Escola Tècnica Superior d'Arquitectura de Barcelona

La línea entre la arquitectura y el diseño muchas veces pierde nitidez; como cuando la reubicación de unas piezas de mobiliario, el ajuste de los dispositivos de iluminación y la aplicación de pinturas en el muro son capaces de redefinir la lectura del espacio y de la estructura que lo determina.

La intervención de Antoni Gaudí y Josep Maria Jujol en la Catedral de Palma de Mallorca fue tan exigua en cuanto a los medios empleados, que es exagerado clasificarla como rehabilitación; mucho más lo sería ver en ella una obra aislada. Fue, en realidad, una obrita de poco cemento y menos picota, apenas unos toques de escarpa en los muros, algunas pequeñas ventanas y un poco de serrucho.

Aún así es una obra importante por presencia en el espacio y por calidad: una obra que sintetiza arquitectura, relieve y pintura porque esta síntesis existe ya en la actividad polifacética de sus autores, que encuentra en algunos momentos el difícil punto de contacto entre la pintura, la arquitectura gótica y el mundo figurativo del Modernismo catalán. La peculiaridad de poder echar mano a todas las artes disponibles, la seguridad a la hora de pintar con incisiones en los muros, la necesaria improvisación del pintor que impide adivinar el resultado previamente a la acción, la presencia constante de los arquitectos en la obra, incluida su ejecución por medio de la propia mano, provocarían una imagen de arquitectos incómodos y estrafalarios para una obra que llevaba consigo la exigencia de un mínimo de protocolo burocrático.

La operación consistió sustancialmente en el traslado del altar mayor a una posición más visible y la ocupación del ábside por las antiguas sillas del coro, con la cual se reemplazaría el antiguo retablo. Para ello era necesario acoplar los muebles a la nueva situación; posteriormente se pintaron, con el objeto de convertirlas en el zócalo de la ornamentación que asciende por las paredes del ábside. Esta ornamentación consiste en un tapiz de piezas cerámicas vidriadas y unas incisiones doradas en los muros.

En medio de la penumbra, unos racimos de lámparas diminutas descienden desde lo alto y emiten una luz que, reflejada en los vidriados y dorados de la decoración del coro y aumentada durante el día por la que penetra a través de las vidrieras, comunica este aspecto inmaterial que podría evocar el producido por los mosaicos de las iglesias bizantinas, pero que también se reconoce en las escenas de la pintura gótica, tantas veces flotando en los fondos irreales de los panes de oro. El elemento más impresionante de la obra es un mueble: una enorme lámpara sobre el altar que define su espacio al modo de un baldaquino flotante y que recibe la respuesta desde el suelo por medio de cuatro columnillas rematadas por ángeles.

Tal vez, porque se trata de una actuación superpuesta, el derroche que Gaudí y Jujol hacen de su conocimiento y de su interés por la arquitectura gótica y la delicadeza con la que buscan la coherencia y la integración en el edificio en el que están actuando es lo que los delata. Es evidente que se trata de dos arquitectos del Modernisme. En las iglesias góticas los retablos, las esculturas, se superponen sin más, porque se sabe que estos espacios lo soportan casi todo; ni siquiera en la abadía

\section{Gaudí and Jujol in Mallorca: quite a pair}

Xumeu Mestre Architect, Escola Tècnica Superior d'Arquitectura de Barcelona Elías Torres Architect, Escola Tècnica Superior d'Arquitectura de Barcelona

The line between architecture and design is often blurred; such as when the relocation of furniture pieces, illumination adjustments and painting are capable of redefining one's reading of the determining space and structure.

The intervention of Antoni Gaudí and Josep Maria Jujol to the Palma Cathedral of Mallorca was so minimal in terms of means, that it's an exaggeration to classify it as a restoration much less an independent work. In actuality it is no more than some cement, touches of escarpment on the walls, a few small windows, a saw and a pickaxe.

Still, important for its spatial presence and quality, the work synthesizes architecture, relief and painting as existed in the multi-faceted activities of its authors revealing some of the difficult points of contact between painting, gothic architecture and the figurative world of Catalan Modernism.

The peculiar ability to put a hand to the arts available, the confidence to paint by incision in walls, a painter's improvisation necessary from the unknown result previous to action, the constant presence of the architects in the work, including the execution of their own hands, would provoke an image of extravagant, eccentric architects buried in a project that demanded at least a minimum effort of bureaucratic protocol.

The most substantial operation consisted of moving the main altar to a more visible position with the chorus occupying the apse in place of the old altarpiece. The arrangement of the newly joined and painted chorus chairs becomes a kind of ornamental transition ascending the walls of the apse and consisting of a layer of glazed ceramic pieces and gold incisions in the walls.

In the dim light, a cluster of petite lamps descend from above and emit a light, reflecting off the gold and glazing of the chorus and augmenting the penetrating daylight through the stained glass that communicates a certain immaterial aspect evoking the light produced by the mosaics of Byzantine churches and the scenes of gothic painting which float through unreal backgrounds of gold. The most impressive element of this work is a furniture piece: an enormous lamp over the altar, defining its space as a floating canopy and receiving its response from the floor by four slender columns crowned by angels.

Maybe intervention treated as superimposition, the exuberance Gaudí and Jujol make of their masterful interest in gothic architecture or the delicacy with which they strive for coherent integration betrays them as two architects of Modernisme. Normally in gothic churches the altarpieces and sculptures are simply deposited, as gothic space seems to allow for anything. In Westminster Abby, the many additions have piled up as in an attic with all the glory of England. One could say that gothic space has been violated.

It's said that just before Gaudí and Jujol left for Barcelona an altar boy heard Gaudí say to Jujol “...si anem així de bé aviat començarem amb la façana"1 and some swear they have seen an outline sketch of 


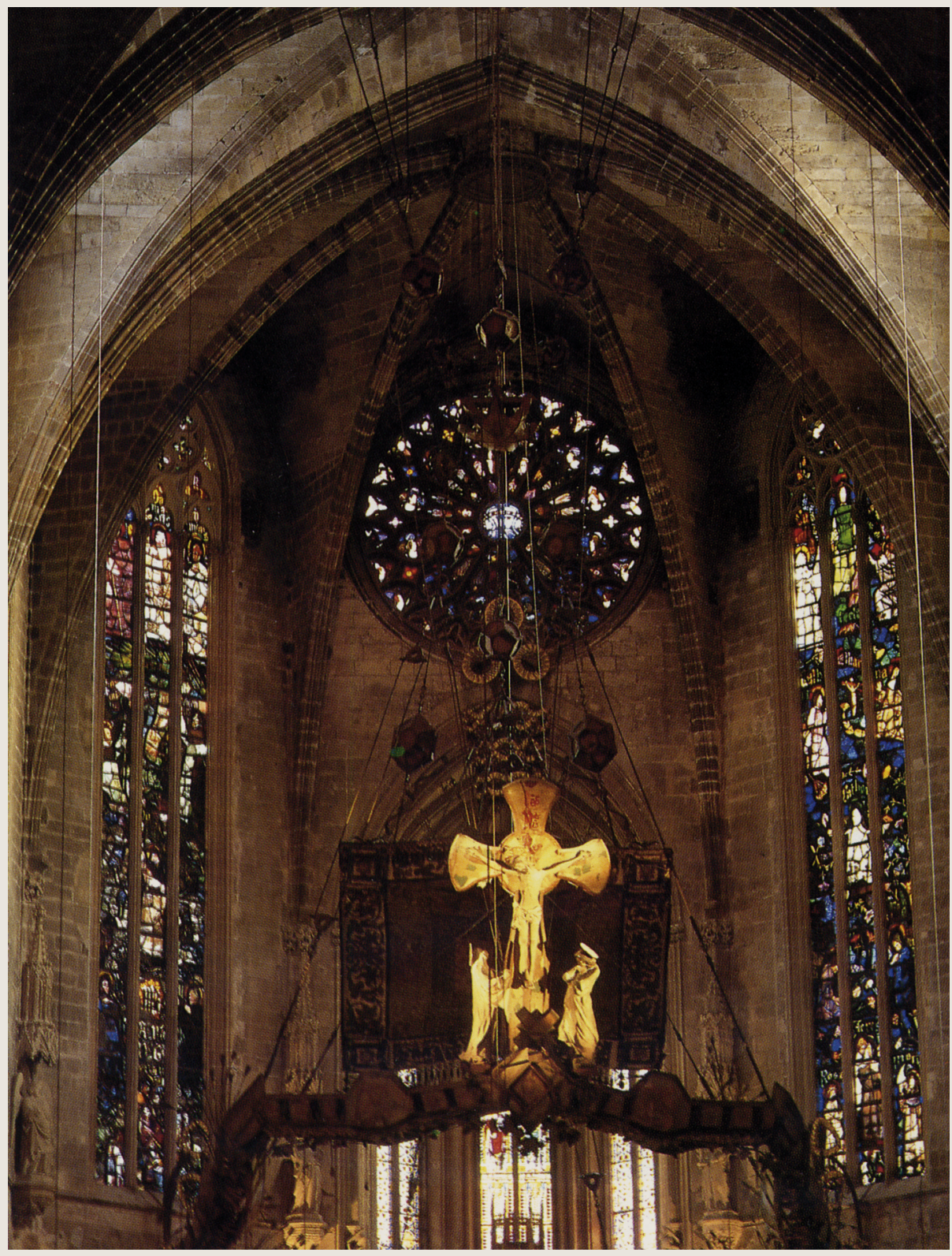

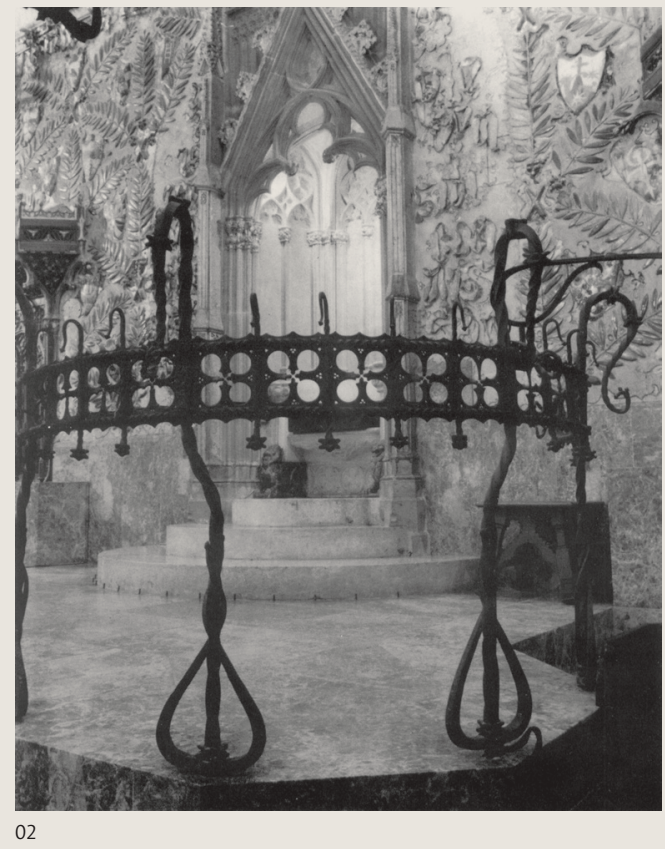

01 Lámpara sobre el altar y vitrales en los ventanales y rosetón de la catedral 02 Protecciones forjadas junto a la Sede episcopal

01 Lamp over the altar and stained glass windows of the Cathedral 02 Wrought iron handrails next to the Episcopal seat 


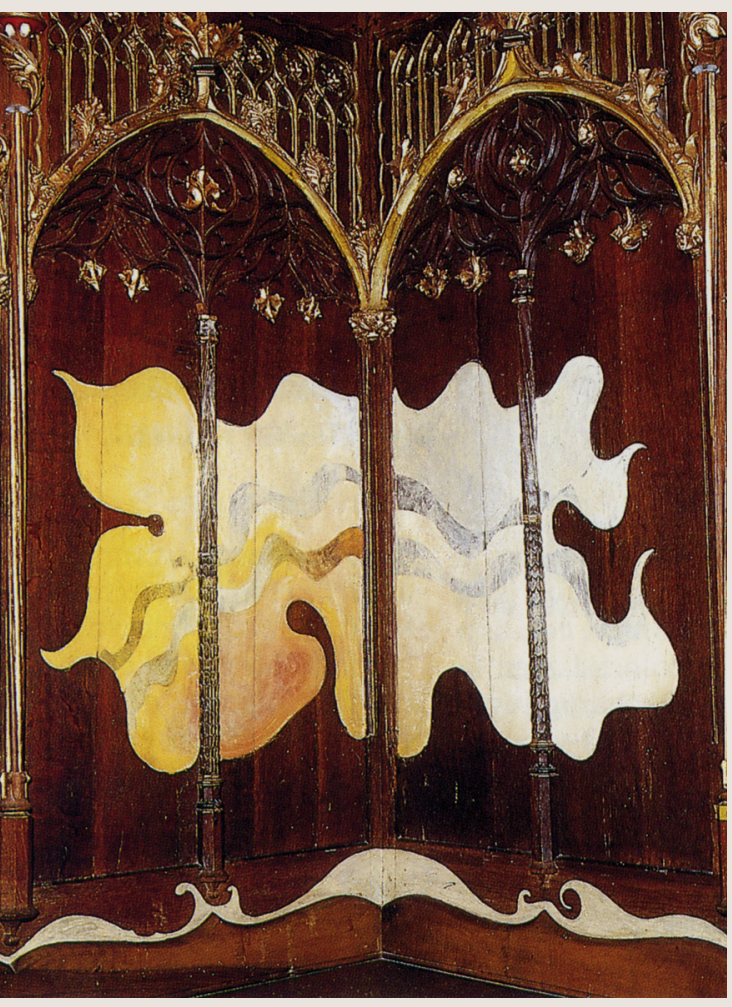

03
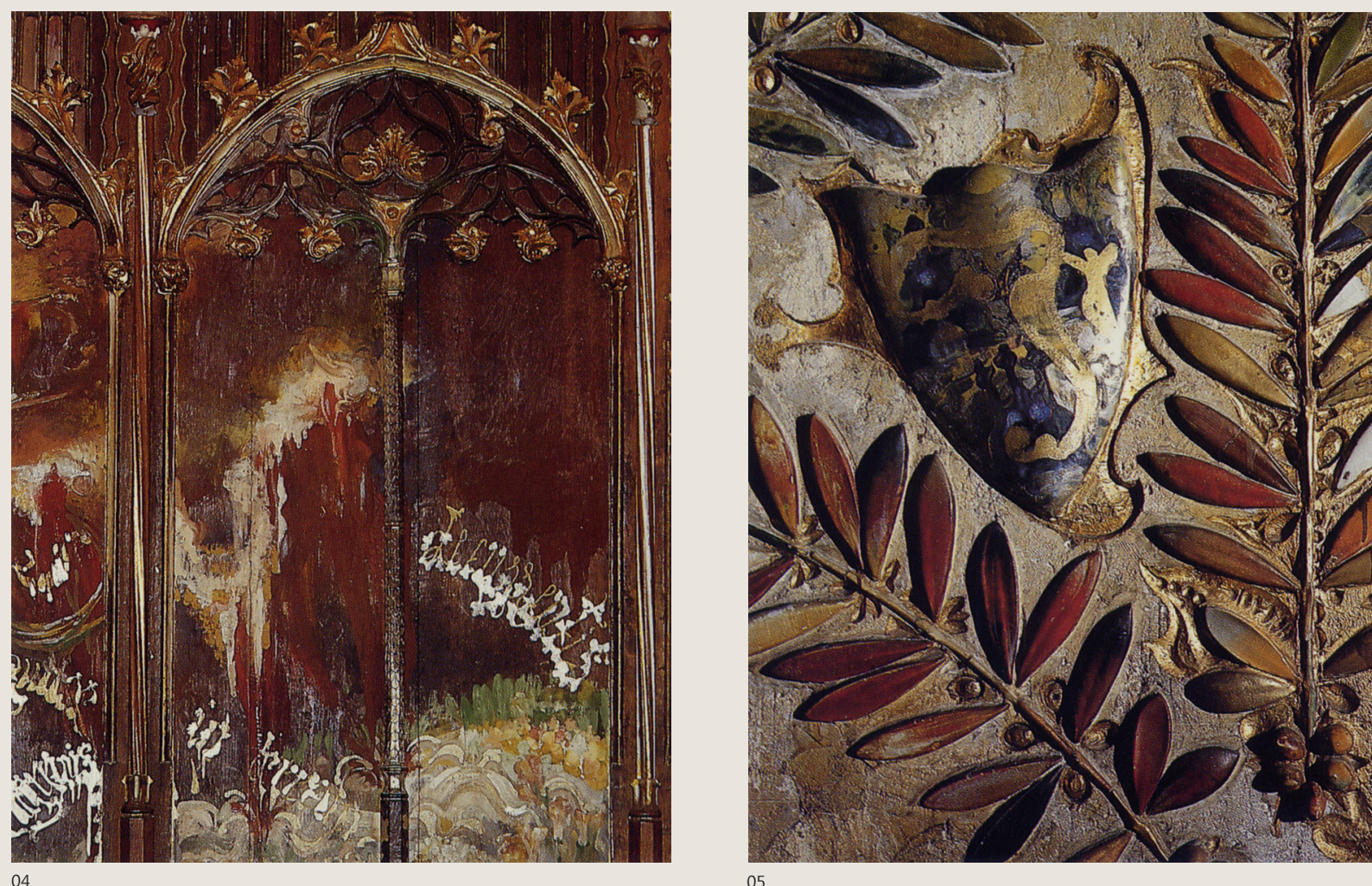
1 "Si vamos así de bien, pronto empezaremos la fachada" ( $\mathrm{N}$.

del ed.).

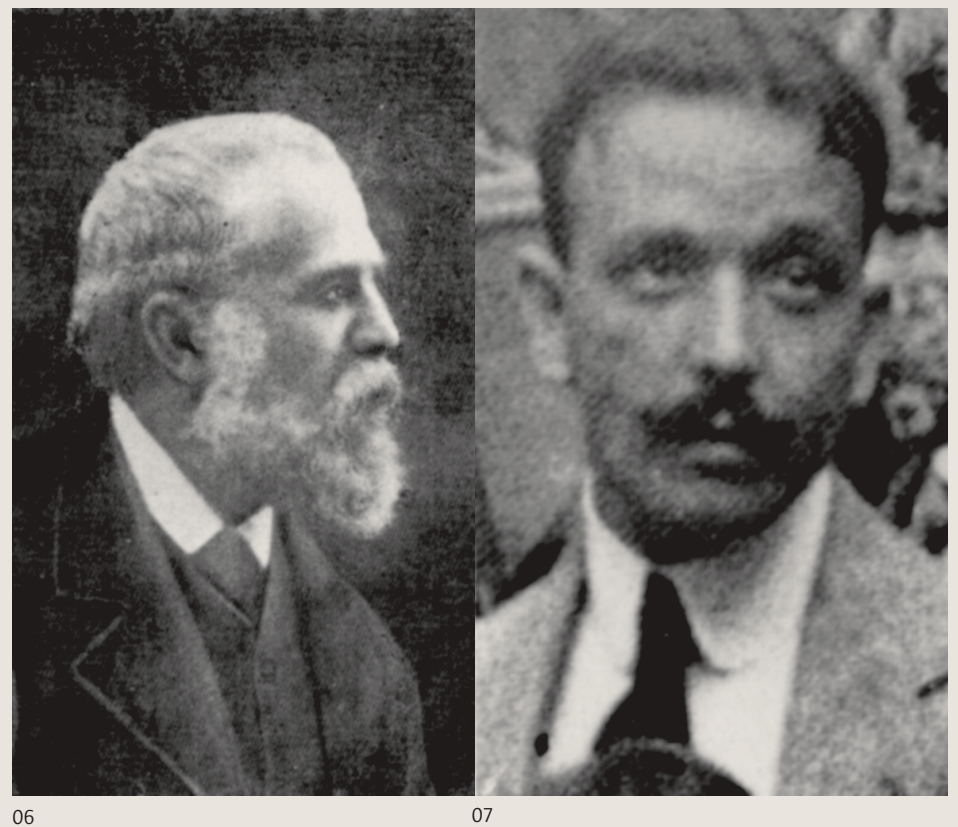

06
07
03 a 05 Detalles de las pinturas aplicadas sobre las antiguas sillas del coro 06 Antoni Gaudí a los 58 años. 1910

07 Josep Jujol a los 34 años. 1913

Fuente de imágenes 1 a 5: Revista D'A №1, pp. 52, 56, 66 y 67.

03 to 05 The paintings covering the antique chorus chairs

06 Antoni Gaudí at 58 years old. 1910

07 Josep Jujol at 34 years old. 1913

Image 1 to 5 source: $D^{\prime} A$ № 1 magazine, pp. 52, 56, 66 y 67. de Westminster, donde las intervenciones sucesivas han amontonado como en un desván toda la gloria de Inglaterra, se podría decir que el espacio gótico haya sido vulnerado.

Se dice que poco antes de que Gaudí y Jujol partieran definitivamente hacia Barcelona un monaguillo oyó a Gaudí decirle a Jujol “...si anem així de bé aviat començarem amb la façana"1 y hay quien asegura haber visto un boceto de la fachada neogótica de Peyronnet hecha un galimatías. Son habladurías difíciles de confirmar por lo que no es cuestión de lamentar la pérdida de lo que no se sabe si se pudo tener. $\mathrm{Al}$ contrario, Mallorca puede hoy celebrar que posee una de las actuaciones arquitectónicas más brillantes, intervención en la que se percibe el entusiasmo y la inspiración de que hicieron gala sus autores Gaudí y Jujol. ARQ

\section{Bibliografía}

Quetglas, Joseph. “A. Gaudí y J.M. Jujol a la Seu”. Revista D’A №1. Col-legi Oficial d'Arquitectes de Balears, Palma de Mallorca, 1989. the Peyronnet's neo-gothic faáade drawn chaotically. The rumors are difficult to confirm as it is not as much a question of loss lamented as the unknown of what could have been. On the contrary, Mallorca today can celebrate possession of one of a brilliant architectonic intervention where one can easily perceive the enthusiastic inspiration illustrated by Gaudí and Jujol. ARq

\section{Bibliography}

Quetglas, Joseph. “A. Gaudí y J.M. Jujol a la Seu”. Revista D’A №1. Col-legi Oficial d'Arquitectes de Balears, Palma de Mallorca, 1989. 